Нойман, Ивэр. 2004. Использование “Другого”: Образы Востока в формировании европейских идентичностей. Москва: Новое издательство. Тейлор, Чарльз. 2004. Мультикультуралізм і “Політика визнання". Київ: Альтерпрес.

\section{REFERENCES}

Fukuiama F. 2018. "Against Identity Politics", Strategic Group Sofia. URL: http://sg-sofia.com. ua/protiv-politiki-identichnosti-fukuyama (in Russian)

Sasse G., Lackner A. 2018. "War and identity: the case of the Donbas in Ukraine". URL: https://www.tandfonline.com/doi/full/10.1080/10 60586X.2018.1452209? scroll=top\&needAccess $=$ true

Giuliano E. 2018. "Who supported separatism in Donbas? Ethnicity and popular opinion at the start of the Ukraine crisis". URL: https://www.tandfonl ine.com/doi/pdf/10.1080/1060586X.2018.1447769?red irect $=1$

Rabotiahova I., Kyselova V. 2016. "Heterogeneity of the post-Soviet habitus on example of the Slov'yansk armed conflict: a methodological framework for the study", Visnyk KhNU Imeni V. N. Karazina Seriia "Pytannia Politolohii”. Вип. 29: 99103. (in Ukrainian)
Horbatenko S. 2019. "New people, old powers: whom the Donetsk region leads to the Rada". URL: https://www.radiosvoboda.org/a/na-donbas-obralyprorosijskykh-politykiv/30069572.html (in Russian)

Byhunov D. 2019. "Homophobia of elections in Slavyansk". URL: http://novosti.dn.ua/article/7394gomofobyya-vyborov-v-slavyanske (in Russian)

Giddens A. 1991. Modernity and Self-Identity: Self and Society in the Late Modern Age. Stanford: Stanford University Press.

Fuko M. 1996. The will to truth: beyond knowledge, power and sexuality. Works of different years. Moscow: Kastal. (in Russian)

Fuko M. 2002. Intellectuals and power: articles and interviews, 1970-1984: In 3 parts. Moscow: Praksys. (in Russian)

Anderson B. 2016. Imaginary community. Reflections on the origins and spread of nationalism. Moscow: Kuchkovo pole. (in Russian)

Taylor Ch. 2004. Modern social imaginaries. Durham: Duke University Press.

Noiman Y. 2004. Use of the "Other": Images of the East in the formation of European identities. Moscow: Novoe izdatelstvo. (in Russian)

Teilor Ch. 2004. Multiculturalism and the "Politics of recognition”. Kyiv: Alterpres. (in Ukrainian)

\section{Olena Bakumenko}

Associate Professor, $\mathrm{PhD}$ in Historical Science Ukrainian Engineering Pedagogics Academy, Universitetska Street, 16, Kharkiv, 61003, bakumenkolena1974@gmail.com, https://orcid.org/0000-0002-3108-6324

Olga Kashaba

Associate Professor, $\mathrm{PhD}$ in Historical Science Ukrainian Engineering Pedagogics Academy, Universitetska Street, 16, Kharkiv, 61003, olga.kashaba@ukr.net, https://orcid.org//0000-0002-0616-145x

Iryna Shcherbyna

Associate Professor, PhD in Historical Science Ukrainian Engineering Pedagogics Academy, Universitetska Street, 16, Kharkiv, 61003, shcheririna63@gmail.com, https://orcid.org/0000-0003-3007-2446

\title{
GENDER EQUALITY IN UKRAINE: ANALYSIS OF LEGAL ACTS
}

Today, in most countries, the equal legal status of women and men, as well as the equal opportunity to execute it in society, that is, gender equality, has long been a commonplace in public discourse and politics. In Ukraine, equality between men and women is declared at the constitutional level, which testifies to the approach of the Ukrainian state and civil society to the European and world level of solving gender problems. 


\section{Вісник ХНУ імені В. Н. Каразіна, серія «Питання політології», вип. 35, 2019}

The execution of the legal regulation of the state gender policy in Ukraine is considered by the normative legal acts of two levels: supranational and national and the results of their implementation.

The actual problem of not only creating a sufficient regulatory and legal field, but also its compliance is analyzed. Moreover, attention is paid to the facts of violation and neglect of the current legislation, which in turn leads to the preservation of gender inequality in Ukrainian society, where most property, power and general influence belong to men. There is a need to develop a new paradigm of state power, which should envisage the optimal use of human resources, in particular its female component and, ultimately, the achievement of gender equality as an important part of the development strategy, which is intended to enable all men and women to improve their living standards. It is argued that the relevance of gender equality in the contemporary historical context will be maintained in the short term. This is due to the fact that the problems of gender inequality, and therefore of socio-economic and political discrimination against women, cannot be solved solely by state reforms, since a system of rules that forbid any deterioration of women's rights is unlikely to operate without an effective system for monitoring of norms implementation.

Keywords: gender equality, democracy, state, state policy, regulatory acts.

Бакуменко Олена

Олексіївна

доцент, к.іст.н.,

Українська інженерно-педагогічна академія, вул. Університетська, 16, Харків, 61003, bakumenkolena1974@gmail.com,

https://orcid.org/0000-0002-3108-6324

Кашаба Ольга Юрї̈вна

доцент, к.іст.н.,

Українська інженерно-педагогічна академія, вул. Університетська, 16, Харків, 61003, olga.kashaba@ukr.net, https://orcid.org//0000-0002-0616-145X Щербина Ірина Володимирівна доцент, к.іст.н.,

Українська інженерно-педагогічна академія, вул. Університетська, 16, Харків, 61003, shcheririna63@gmail.com,

https://orcid.org/0000-0003-3007-2446

\section{ГЕНДЕРНА РІВНІСТЬ В УКРАЇНІ: АНАЛІЗ НОРМАТИВНО-ПРАВОВИХ АКТІВ}

Сьогодні у більшості країн рівний правовий статус жінок $і$ чоловіків, а також рівність можливостей для його реалізаиії у житті суспільства, тобто гендерна рівність, давно стали загальним місием у публічному дискурсі та політиці. В Україні рівність між чоловіками $і$ жінками задекларована на конституційному рівні, що свідчить про вихід українськоӥ держави й громадянського суспільства на європейський $i$ світовий рівень розв'язання гендерних проблем.

Розглядається здійснення правового регулювання державної тендерної політики в Україні нормативно-правовими актами двох рівнів: наднаціонального та національного та результати їхнього впровадження.

Аналізується актуальна проблема не тільки створення достатнього нормативноправового поля, а і його дотримання. Причому звертається увага на факти порушення та ігнорування чинного законодавства, що в свою чергу спричинює консервацію гендерної нерівності в українському суспільстві, де більшість власності, влади $і$ загального впливу належать чоловікам. Доводиться необхідність вироблення нової парадигми державної влади, яка має передбачити оптимальне використання людського ресурсу, зокрема його жіночої складової та у кінцевому рахунку досягнення тендерної рівності як важллиої частини тієі стратегії розвитку, яка покликана дати можливість усім, $і$ чоловікам, і жінкам, підвищити 
свій життсвий рівень. Доводиться думка про те, щэо актуальність проблеми тендерної рівності у сучасному історичному контексті зберігатиметься у найближчий перспективі. Зумовлено це тим, щуо проблеми тендерної нерівності, а відтак і соціально-економічної та політичної дискримінації жінок не можуть бути розв язані лиме державними реформами, оскільки система норм, щзо забороняють будь-яке погіршення прав жінок, навряд чи прачюватиме без дієвої системи контролю за виконанням циих норм.

Ключові слова: гендерна рівність, демократія, держава, державна політика, нормативно-правові акти.

Бакуменко Елена Алексеевна доцент, к.ист.н., Украинская инженерно-педагогическая академія, Ул.Университетская, 16, Харьков, 61003, bakumenkolena1974@gmail.com

https://orcid.org/0000-0002-3108-6324

Кашаба Ольга Юрьевна доцент, к.ист.н., Украинская инженерно-педагогическая академія, ул.Университетская, 16, Харьков, 61003, olga.kashaba@ukr.net https://orcid.org//0000-0002-0616-145X

Щербина Ирина Владимировна доцент, к.ист.н., Украинская инженерно-педагогическая академія, ул.Университетская, 16, Харьков, 61003, shcheririna63@gmail.com https://orcid.org/0000-0003-3007-2446

\section{ГЕНДЕРНОЕ РАВЕНСТВО В УКРАИНЕ: АНАЛИЗ НОРМАТИВНО-ПРАВОВЫХ АКТОВ}

Сегодня в большинстве стран равный правовой статус женщин и мужчин, а также равенство возможностей для его реализации в жизни общества, т.е. гендерное равенство, давно стали общим местом в публичном дискурсе и политике. В Украине равенство между мужчинами и женщинами задекларировано на конституционном уровне, что является свидетельством выхода украинского государства и гражданского общества на европейский и мировой уровень решения гендерных проблем.

Рассматривается осуществление правового регулирования государственной гендерной политики в Украине нормативно-правовыми актами двух уровней: надначионального и национального и результаты их внедрения.

Анализируется актуальная проблема не только создания достаточного нормативноправового поля, а и его выполнение. Причем обращается внимание факты нарушения $и$ игнорирования действующего законодательства, что в свою очередь создает условия для консервации гендерного неравенства в украинском обществе, где большинство собственности, власти и общего влияния принадлежит мужчинам.

Доказывается необходимость разработки новой парадигмы государственной власти, которая должна предусмотреть оптимальное использование человеческих ресурсов, в частности их женской составляющей, и в конечном итоге достижение гендерного равенства как важной части той стратегии развития, которая призвана дать возможность всем, и мужчинам, и женщинам, повышать свой жизненный уровень. Доказывается тезис о том, что актуальность проблемы гендерного равенства в современном историческом контексте сохранится в ближайтей исторической перспективе. Обусловлено это тем, что проблемы гендерного неравенства, а, следовательно, и социальноэкономической и политической дискриминации женщин не будут решены только при помощи государственных реформ, так кат система норм, запрещзающих любое ухудшение прав женщин, навряд ли будет работать без системы контроля за их выполнением.

Ключевые слова: гендерное равенство, демократия, государство, государственная политикак, нормативно-правовые акты. 
$\mathbf{O}_{\text {ver the past decades, the problem of gender }}$ equality has become a common place in public discourse and politics. Governments, business community, trade unions, public organizations from different countries make many efforts to overcome discriminatory stereotypes, which create obstacles for ensuring equal legal status of men and women, as well as equal opportunities for its realization in public life.

Ukraine belongs to the countries where significant changes are occurring in the understanding and legitimization of gender relations, constantly taking steps to introduce an institutional mechanism for ensuring gender equality. Despite this, de facto Ukrainian society remains unbalanced on this issue. There are still manifestations of gender discrimination

That is why this problem is relevant. Uncertainey of gender priorities and postponing the issues resolution of gender inequality to the background provoke negative consequences for all spheres of public life.

The debate on the introduction of gender equality in the European countries was particularly acute in the twentieth century. From the same time, begins an active scientific development of this problem. Thus, among the western scholars, socio-cultural determinants of gender, the impact of gender on management, gender policy and stereotypes are studied by D. Best, J. Williams, K. Jacklin, A. Erhard, E. McCoy, J. Mani, M. Mead, K. Petman, J. Rozner. S. Salmaniemi, M. Shenli, L. Shrag and others. In Ukraine, this problem is today one of the most relevant and researched. The domestic humanities analyze the mechanisms of gender policy formation, the legal framework for women's participation in political and public life, gender equality and discrimination. Such researchers as M. Bogachevstka-Khomyak, O. Vilkova, N. Hrytsiak, H. Daudov, I. Zherebkina, L. Kobylyanska, T. Kremeshna, T. made a significant contribution to the study and popularization of these issues. Martsenyuk, O. Osaulenko, A. Pashko, L. Smolyar, S. Stanik, O. Yarosh and others. But at the same time, despite the increasing popularity of gender issues, it remains in Ukraine as a marginal segment of research and needs special attention.

These and other scientific developments necessitate the study of legal regulation of equal rights and opportunities of women and men in Ukraine, which may be carried out by analyzing and classifying normative legal acts on the state provision of equal rights and opportunities for women and men in Ukrainian society. In the context of such a study, it will also be useful to identify ways to improve the legal framework for ensuring this process.

Equality of male and female social articles is the basis of all human freedoms. The Human Development Report 2000 prepared by the United Nations Development Program identifies seven fundamental freedoms: freedom from discrimination - on the basis of gender, racial, ethnic, national or religious beliefs; freedom from poverty; the right to a decent standard of living; freedom from fear - from threats, special danger, from torture, arbitrary arrests and other acts of violence; freedom from injustice and violations of law; freedom of thought, speech, participation in the decision-making process and the formation of associations; freedom to work decent, not to be exploited. Consequently, equality of social status means universal participation in all spheres of social, public and private life on the basis of self-awareness of personal needs and interests, overcoming elements of superiority, for which men were historically considered higher, and the results of their activities were pre-evaluated as socially more significant than those that have been achieved by women.

Equality of rights means empowering men and women with legally equal rights in all spheres of life and providing them with legal conditions for equal enjoyment of their rights.

However, equality of rights does not mean the actual ability to enjoy the rights and freedoms of a person irrespective of sex. This becomes possible due to the equality of opportunities provided by the system of equal means of distribution of values, eliminates discrimination on the basis of sex, and avoids any possibility of negative influence on the vital functions and expression of a person (Гаман, Курига 2011: 420).

As part of our study, the concept of gender equality should be considered. Modern democracy has proclaimed the principle of equality of all before the law. The legal principle of equality means the absence of any restrictions on the rights of individuals and civil liberties.

Implementation of this principle is possible provided that there is a fair social system in which political and legal realities ensure the maximum observance of the rights of the individual.

In the legal aspect, gender equality functions as a component of the general principle of equality. Gender equality is different from the other structural elements of the principle of 
legal equality, namely equality regardless of age, nationality, race, although it is based on a natural-legal concept. The construction of gender equality should be disclosed primarily through the category of human rights as a universal equality standard, which is the only one for both sexes.

The category of gender equality involves a plurality of components, namely:

- Equality of rights. This means that men and women are legally entitled to the same rights.

- Equality of opportunity. Legislation not only declares, but also guarantees equal conditions for equal distribution, the use of political, economic, social and cultural values that exclude discrimination and restrictions of any gender that negatively affect livelihoods and self-expression.

- Ensuring equal conditions for the realization of rights and opportunities.

- «Gender symmetry». Creating an appropriate environment for implementing the principle of equal rights and opportunities by representatives of both sexes in practice (Крочук 2011: 468-469).

Thus, gender equality means equal opportunities for self-realization of women and men, guarantees respect for rights and freedoms, taking into consideration the peculiarities of the articles, mutual responsibilities and shared responsibility in the process of life activity.

Gender equality implies a society in which both women and men have equal opportunities, rights and responsibilities in all spheres of life. Equality between women and men is when people of both sexes can have equal access to education and health care, authorities, have equal opportunities to achieve financial independence, working for someone or managing their own business. It also means the possibility of equal realization of their personal and professional needs and interests. A critical aspect in achieving gender equality is the empowerment of women and greater opportunities in various spheres of social development, as well as the involvement of men in the process of achieving gender equality (Дашковська 2014: 20-23).

Therefore, the American political scientist Ronald Inglhart in «Gender equality and democracy», noted that «gender equality - a sensitive indicator that shows how advanced and democratic state is». Currently, we can clearly observe that developed societies are gradually moving from a cruel hierarchical style of management to a more collegial one. Hierarchical style or conditionally «male» focuses attention on domination and competition, while collegiate style and, accordingly, «feminine» puts the lead in leadership - cooperation and support. That is why it is considered more effective to maintain the stability of public institutions.

In general, affirmation of gender equality is part of a broad cultural transformation that changes the functioning of traditional societies and promotes the development of democratic institutions (Грицяк 2006 ). Adoption of the value of gender equality ensures the transition to post-materialist values of self-realization, which contribute to the economic development of countries. That is why, one of the conditions for Ukraine's accession to the European Union is to build a gender-balanced society on its territory, in the long run, a parity of democracy.

The term «parity democracy», which is actively used in the Ukrainian sociohumanitarian analysis, is the term «gender democracy». «Gender democracy involves establishing equality of rights, freedoms, responsibilities, compliance and chances of men and women in the life of society, state and selfdevelopment of their own personality». ««Parity democracy» - a political and legal form of organization of social and sexual relations in a society in which women and men have equal legal and political status and as equals represented and carry out activities in genderbalanced bodies of power and administrative structures» ( Кобилянська 2005: 153).

That is why one of the conditions for Ukraine to get the membership in the European Union is the construction of a gender balanced society on its territory, in the long run, a parity democracy.

Compliance with the term «parity democracy», which is actively used in the Ukrainian socio-humanitarian analysis, is the term «gender democracy». «Gender democracy» implies the assertion of the equality of rights, freedoms, responsibilities, compliance and chances of men and women in the life of society, the state and the self-development of one's own person. «Parity democracy» is a political and legal form of organization of social-sexual relations in a society in which women and men have equal legal and political status and are equally represented and carry out activities in gender-balanced bodies of power and administrative structures» (Кобилянська 2005: 153).

Proceeding from the content of the concept of «parity democracy», it is possible to distinguish several of its parameters: equal representation of women and men in elected 
and appointed positions; gender balance in the legislative process; equal rights and equal opportunities for participation in public life and politics of all citizens, regardless of gender. However, it should be noted at once that the gender imbalance in Ukraine is a form of relative humiliation of the rights of both women and men.

Consequently, gender parity is the principle of equal representation of women and men, equality and equality in all spheres of public life (Гаман, Курига 2011: 419).

Gender equality is an ideological component of state policy and public administration, which has four dimensions, which underlie the directions of development of state gender policy at the present stage of development of Ukrainian society. The first dimension of gender equality is human rights as a universal standard of political, civil, economic, social and cultural rights and freedoms for women and men. The second dimension of gender equality is human rights as women's rights. The third dimension is the equality of freedoms, rights and responsibilities. Fourth - equal opportunities - the main element of gender equality (Грицяк 2004: 325-332).

Gender equality is also defined as: the process of fair treatment of women and men; one of the important features of the rule of law; indicator of the level of development of an open society; the condition of prosperity and the development of democracy.

The peculiarity of the formation of the state gender policy in Ukraine is that it is based on the international legal acts ratified by Ukraine and national legal documents on equality between women and men. Consequently, the legal regulation of state gender policy is carried out on two levels: international and national.

With the efforts of the international community, a number of important policy initiatives have been developed and implemented to ensure gender mainstreaming through the development of a normative framework, technical assistance, and institutional mechanisms. After all, the achievement of gender equality is now becoming a central indicator of the development of each country, and in a globalized world, modern society is forced to address gender stereotypes at once. The UN considers this problem to be a global category and recommends that states modify existing gender models aimed at preserving the system of unequal values and double standards.

Equality of rights and freedoms of a person and a citizen regardless of gender is determined and guaranteed by a number of documents that Ukraine, as a member of the United Nations, is obligated to implement.

The most important international document in the field of gender equality is the Convention on the Elimination of All Forms of Discrimination against Women (CEDAW). It is the only comprehensive international instrument of universal character that will oblige states to guarantee the observance of women's rights and combat discrimination against women in areas such as education, labor, health, family policy, finance, legislation, and socio-political spheres.

States that have ratified the Convention, and try to adhere to the principle of gender equality, should «take all necessary measures, including measures in the field of legislation and temporary special measures, so that women can enjoy all their human rights and fundamental freedoms» (Конвенція ООН про ліквідацію всїх форм дискримінації 1979). This implies that States are committed to introduce and implement a number of activities aimed at combating discrimination against women and the creation of appropriate conditions to prevent this phenomenon.

The second important international document is the Beijing Declaration and Platform for Action (BPfA), adopted by the United Nations in 1995 (Пекінська декларація. Параграф 7 1995). The Declaration laid the foundations for empowerment of women. The document states that «full realization of all human rights and fundamental freedoms of all women is important for empowerment of women» (Пекінська декларація. Параграф 9 1995). The Beijing Declaration and Platform for Action emphasize the importance of developing and implementing a variety of gender equality mechanisms that «should ensure the integration of gender perspectives into legislation, public policies, programs and projects» (Пекінська декларація. Параграф 196-208 1995;). These mechanisms should work at all levels: national, regional and local.

To date, the UN Security Council has adopted eight resolutions on gender (8 Резолюцій Ради Безпеки $\mathrm{OOH}$ 2000;2009;2010;2011;2013;2015).

On 31 October 2000, resolution 1325 «Women, Peace, Security» was adopted. This document emphasizes the important role of women in preventing and resolving conflicts, peaceful negotiations, peace-building, humanitarian and post-conflict reconstruction activities, while emphasizing the importance of their equal participation and full involvement in activities aimed at promoting peace and 
security. It emphasizes the need to increase the participation of women, the implementation of a gender perspective in all UN activities on peace and security, and the implementation of special measures to protect women and girls from gender-based violence (Основоположна резолюція «Жінки. Мир. Безпека» 2000).

The European vector of development of our state involves fulfilling the basic EU documents on creation of conditions for gender parity. The fact is that European integration, in the broad sense of the essence of this process, means adapting to the norms of European legislation, increasing the competitiveness of the domestic market economy, as well as reforming and developing political institutions able to ensure the full functioning of a social-legal democratic state on the basis of civil society, its constructive dialogue and cooperation with political-power structures. It is aimed at adapting Ukraine to the modern European system through its gradual entry into the relevant structures of the EU.

Therefore, the ratification of the Partnership and Cooperation Agreement between Ukraine and the European Community has become an important milestone for the development of our society. It convinced the extraordinary importance of the rule of law and respect for human rights. The Partnership and Cooperation Agreement became the first document signed on June 16, 1994 and was ratified by the Law of Ukraine No. 237/94 - VR of November 10, 1994.

By its thematic scope, the Agreement is the largest international legal document in the history of Ukraine and one of the largest international treaties with a third country ever concluded by the European Union (Білосорочка 2017: 2).

Chapter 21 of the fifth section of the Agreement is devoted to cooperation in the field of employment, social policy and equal opportunities, it is about the scope of cooperation, namely that the parties to the agreement «strengthen dialogue and cooperation in terms of decent work, employment policy, safe and healthy working conditions, social dialogue, social protection, social inclusion, gender equality and nondiscrimination» (Білосорочка 2017: 2).

On November 9, 1995, Ukraine became the 37 th country (out of 47) - a member of the Council of Europe, and therefore committed to uphold fundamental values for the Council of Europe: human rights, democracy and the rule of law, gender equality and women's participation in politics.
The Committee of Ministers of the Council of Europe developed a number of recommendations on gender issues for member states. Namely:

- Gender equality standards and mechanisms. This recommendation concerns areas that are particularly important for achieving gender equality (economic life, a balance between personal and professional life, social protection, counteracting violence against women, etc.) (Рекомендація CM/REC 17 країнам-членам про стандарт гендерної рівності 2007).

- Gender approach at the local and regional levels. The document emphasizes the importance of gender equality mechanisms as a defining support system aimed at helping those who are involved in developing policies and providing services, concepts and implement the concept of gender equality, as well as how to track progress and encourage accountability of individuals involved in work (Рекомендація 148 Ради Європи про гендерний підхід 2004).

- Gender oriented budgeting. The Recommendation encourages regional and local authorities to implement gender sensitive budgeting tools and procedures as part of public finance reform (Проект 3 питань гендерно чутливого бюджетування GRB project).

- Combating the growing poverty among women. The resolution encourages member states to take into account the gender dimension of poverty and take into account the increasing poverty rate among women in the fight against poverty (Резолюція Ради Європи 319 про боротьбу з зростаючою бідністю 2015).

In 2006, the Council of European Municipalities and Regions (CEMR) developed the European Charter for Equality of Women and Men at the local level. Charter ratified almost all cities in Europe. In Ukraine, this movement is just beginning, the relevant decision was taken in 2017 Vinnitsa, and in 2018 - Zhytomyr and Irpin.

The Charter provides clear recommendations to local governments on measures within their competence, which should be implemented to ensure equality between men and women (as well as national minorities, disabled persons, internally displaced persons, etc.). In addition to promoting gender equality and equal opportunities, the document also describes the importance of carrying out a gender analysis of local decisions, consulting various issues with men and women, and developing gendersensitive social services. According to this document, local governments are obliged to develop an action plan for the implementation 
of gender equality policies, and are encouraged to develop and share best practices between cities and regions (Свропейська хартія рівності жінок і чоловіків 2006).

In addition to the above-mentioned documents, the European Union has adopted a number of legal acts in the field of gender equality. In particular, the EU Action Plan on Gender Issues for 2016-2020. It is based on several important principles:

- ensuring the physical and psychological integrity of girls and women;

- promotion of social and economic rights, empowerment of girls and women;

- strengthening the voice of girls and women;

- a change in the institutional culture to more effectively fulfill the European Union's commitments (План дій $\mathrm{EC} 3$ гендерних питань 2016).

In order to comply with international standards and ensure equality of rights among all citizens, Ukraine has adopted a number of legal acts that prohibit any discrimination and promote equality.

The development of gender legislation in Ukraine is taking place at a rather rapid pace. Today the legal base on gender equality is gradually being reduced to international standards.

The main normative legal act of Ukraine aimed at the implementation of equal rights and opportunities by women and men is the Constitution, which enshrines the equality of rights of women and men. The Constitution of Ukraine, as the supreme law of the state, in Article 24 proclaims equal constitutional rights and freedoms of citizens, as well as their equality before the law. According to the Constitution, «Equality of rights for women and men is ensured by: providing women with equal opportunities with men in socio-political and cultural activities, in obtaining education and training, in work and remuneration for it; special principles on labor protection and health of women, establishment of pension privileges; creating conditions that enable women to combine work with motherhood; legal protection, material and moral support for motherhood and childhood, including the provision of paid leave and other benefits to pregnant women and mothers» (Про забезпечення рівних прав i можливостей 2005). In 2005, a special legislative act on gender issues - the Law of Ukraine «Ensuring Equal Rights and Opportunities for Women and Men» - was adopted on the development of these provisions of the
Constitution, which became a practical embodiment of the main principles of gender equality. In accordance with the law, equality of rights of women and men lies in the absence of restrictions or privileges on the basis of sex. The preamble to the Law «On the Guarantee of Equal Rights and Opportunities for Women and Men» outlined the main objective of this document «to achieve the parity of women and men in all spheres of society's life through the legal provision of equal rights and opportunities for women and men, the elimination of genderbased discrimination and the application of special temporary measures aimed at eliminating the imbalance between the opportunities of women and men to realize the equal rights granted to them by the Constitution and laws of Ukraine».

The Law The law identifies five priority directions that create the basis for the formation of gender parity:

1. Participation of women in politics.

2. Fighting gender-based violence.

3. Economic empowerment of women.

4. Responding to the needs of women in the conflict (including internally displaced women and women in the security sector).

5. Fighting gender-based stereotypes and promoting gender equality.

The purpose of this document is the statement of equal rights for the representatives of both sexes. Consider some of its provisions.

Article 1 defines that gender equality is an equal legal status of women and men and equal opportunities for its realization, allows people of both sexes to perceive equal participation in all spheres of society's activities (Законодавство України 3 гендерної рівності).

Article 3 aims to establish gender equality by overcoming gender-based discrimination, ensuring equal participation in the decisionmaking process, the introduction of positive measures, support for fatherhood and a balance between career and personal life.

The said Law was the beginning of the development of national legislation in the field of ensuring equal rights and opportunities for women and men. It should be noted that all Further regulatory acts of the national level are aligned with this Law.

The Law of Ukraine «Ensuring Equal Rights and Opportunities for Women and Men» is a basic principle in the field of gender policy. After its adoption, the National Mechanism for Equal Rights and Opportunities for Women and Men was developed. It was supposed to include legislative institutions, central executive 
authorities, local self-government bodies, the Institute of Gender Advisers and the Ukrainian Parliament Commissioner for Human Rights. Active cooperation with public organizations was foreseen.

According to the Law, during 2006-2010, working groups and coordination councils on family issues, gender equality, demographic development, prevention of domestic violence and counteraction to human trafficking were created in central executive authorities and regional state administrations. A representative of the Ombudsman on the rights of the child, non-discrimination and gender equality has been introduced in the structure of the Human Rights Ombudsperson of the Verkhovna Rada of Ukraine. Also, was established an Expert Council on the Treatment of Access to Discrimination Based on Sex Discrimination

In compliance with the Law «On Equal Rights and Opportunities for Women and Men», state programs for ensuring gender equality were developed and implemented. We can highlight the following:

- The State Program on the Approval of Gender Equality in Ukrainian Society for the Period till 2010, approved by the Resolution of the Ukrainian Cabinet of Ministers No. 1834 dated December 27, 2006;

- The State Program for Equal Rights and Opportunities for Women and Men for the period up to 2016, approved by the Resolution of the Ukrainian Cabinet of Ministers No. 717 dated September 26, 2013.

In order to unify and ensure the consistency and sustainability of the activities of state bodies in ensuring equality of rights and opportunities for all people in 2012, was adopted the Law «Principles of Prevention and Counteraction of Discrimination in Ukraine». According to Article 7 of the Law, state policy on prevention and combating of discrimination aims at: preventing discrimination; application of positive actions; creation of conditions for timely detection of discrimination cases and ensuring effective protection of persons and / or groups of persons who have suffered from discrimination; education and propaganda among the population of Ukraine respect for people regardless of their specific features; dissemination of educational activities in this area.

Article 6 of the Law «Principles of Prevention and Countering Discrimination in Ukraine» prohibits discrimination by state authorities, local self-government bodies, officials, legal persons of public and private law, as well as individuals. In addition, Article
10 of the Law refers to the powers of the Ombudsman to prevent and combat discrimination in the private sphere, to appeal to the court with allegations of discrimination in order to protect public interests.

Article 4 of the Law extends its effect to the following spheres of public relations: public-political activity, public service and service in local self-government bodies, justice, labor relations, health care, social protection, housing relations, access to goods and services, and other spheres public relations.

Ukraine has also ratified the Recommendations of the Special Session of the UN General Assembly "Women in 2000: equality between men and women, world development in the 21st century», The UN Millennium Declaration, in which the heads of 189 states and governments recognized their collective responsibility for maintaining human dignity and equal rights. . At the end of 2016, a campaign was launched in Ukraine to ratify the Council of Europe Convention on preventing and combating violence against women and domestic violence (Istanbul Convention). Unfortunately, this document was not adopted.

The signing of the above-mentioned documents obliges our state to comply with the recommendations of international organizations and to substantially change the principles of organization of state and political governance. To determine for itself the provision of gender equality as an important component of further development and as one of the priorities of state policy.

The gender legislation of Ukraine includes the Code of Labor Law, the Family Code, the Civil and Criminal Codes, the laws on education, pensions, state assistance to families with children, labor protection, the basis of legislation on health protection, etc. In 2000, the Law of Ukraine «On the Prevention of Violence in the Family», the Declaration on the Common Principles of the State Policy of Ukraine on Family and Women, and the Concept of State Family Policy were adopted. In 2001, the President of Ukraine issued a decree «On increasing the social status of women in Ukraine» (Про забезпечення рівних прав i можливостей 2005).

Following the Beijing Conference, two National Action Plans for the Advancement of Women were drafted and adopted: for 19972000 and 2001-2005, and in 2006, the State Program for the Promotion of Gender Equality in Ukrainian Society for the period until 2010, which is still relevant. 
In 2000, UN Millennium Development Goals (mandatory for 2015) were ratified, among which the goal of «ensuring gender equality» was defined. Within this objective, Ukraine has set two goals:

1. To ensure a gender ratio at the level of not less than 30 to $70 \%$ of a gender in representative bodies of government and higher levels of executive power.

2. Reduce the gap between the income of women and men.

The listed tasks were aimed at ensuring gender equality in the political sphere and the labor market in Ukraine.

At the regional level, the «Millennium Development Goals» was also adopted for each specific region. Ensuring gender equality has become an integral part of these documents. On the basis of the Millennium Development Goals, regional programs for socio-economic development were to be developed for the regions, but for the most part, gender priorities were «dissolved» in the programs related to family, youth and childhood.

A new impulse for the development of gender policy in Ukraine was the Association Agreement with the European Union. Ensuring equal opportunities for women and men, combating discrimination are important goals of cooperation, defined by the Agreement. These principles, combined with the implementation of the best EU practices, allowed the preparation of a «State program for ensuring equal rights and opportunities for women and men for the period up to 2016». Also in 2016, the gender issue was included in the «Strategies for the Development of Public Administration for the Period 2016 - 2020». In August 2016, the Ministry of Social Policy announced the draft Concept of the state program for ensuring equal rights and opportunities for women and men for the period up to 2021. However, delaying the adoption of the Concept by the Cabinet of Ministers of Ukraine slowed down the development of this document.

A positive step was the development by the Ministry of Education and Science of Ukraine of the Strategy for the Implementation of Gender Equality and Non-Discrimination in Education «Education: Gender Dimension 2020». However, this Strategy is still not approved by the Cabinet of Ministers of Ukraine.

The Decree of the Cabinet of Ministers of Ukraine No. 113-r of February 24, 2016 approved the National Plan of Action for the implementation of UN Security Council resolutions 1325 «Women, Peace, Security» until 2020. It includes six components:

1. Peacekeeping activities.

2. Participation of women in the establishment of peace.

3. Prevention of conflict and violence.

4. Protection of women and girls who suffered from conflicts.

5. Assistance to people affected by the conflict and their rehabilitation.

6. Monitoring the implementation of the National Plan of Action to implement the UN Security Council Resolution 1325 «Women, Peace, Security» for the period until 2020.

However, the Plan did not receive positive assessments by experts.

As already noted, Ukraine has not ratified the Istanbul Convention (Конвенція Ради Європи CETS №210 2011). Nevertheless, in 2017, changes were made to the legislative framework. For example, the Verkhovna Rada endorsed the criminal responsibility for domestic violence and introduced mechanisms to protect victims of physical, psychological or economic violence (Домашне насильство відтепер є кримінальним 2017).

On June 7, 2017, the Cabinet of Ministers of Ukraine approved the post of Governmental Commissioner for Gender Policy and approved the relevant Provisions. But there are any real mechanisms of influence, they are reduced, mainly to information and expert functions. In particular, obtaining information from officials and organizations, preparing requests and reports, informing citizens through means of information on ensuring equal rights and opportunities for women and men, the right to initiate the creation of expert groups and to convene meetings, as well as to participate in meetings of the Cabinet of Ministers and other government structures with the right of an advisory voice (Постанова КМУ № 390 2017).

Consequently, the main measures and objectives of gender equality policies are defined in the legal and legislative frameworks. However, there is still a gap between procedures and institutional instruments that should ensure the implementation of the gender perspective in local politics, the participation of women in public life, or the development of targeted measures for the advancement of women.

The gender approach is still not widely accepted, and gender equality is considered a purely female problem. Because of this perception, gender equality is not a priority for local and regional authorities, especially in the context of conflict and limited financial 
resources, as well as the lack of state support in this area.

Despite the existence of international normative legal acts ratified by Ukraine and the national legal framework for equality between women and men, we can observe examples of gender discrimination.

The establishment of gender equality faces a number of problems and contradictions in Ukrainian society. Gender imbalance is largely due to traditions and certain stereotypes that prevent the full realization of the representatives of both sexes.

Gender inequality in Ukrainian society is a consequence of both the policy of solving the women's issue in the USSR and the specifics of the post-Soviet transit.

Even in Soviet times, women had great opportunities for work, but in the conditions of their unequal segregation, their wages were on average less than that of men. In the Soviet Union, women could receive education on an equally with men, so even now there is a positive imbalance in obtaining women in higher education. They also had less, and sometimes even more, marital and family rights. At the same time, women tended to bear the triple burden of work: not only in the formal but also in the informal economy, for example, in the natural economy, as well as the main carers of children and domestic workers.

In the post-Soviet period there was a certain revival of patriarchal ideology and practices that consolidated and deepened the inequality that developed during the Soviet Union. The matter is not only in patriarchal stereotypes, which are now shared by many people. The systemic crisis in the conditions of the transformation of society was characterized by a certain return to archaic collectives and methods of redistribution of limited resources based on male domination. All these trends have formed the basis for discrimination against women in many areas of public life, which are quite difficult to overcome.

Periodically, the World Economic Forum provides a report on the global gender gap, calculating the gender equality index. This option is calculated on the basis of male and female gender ratios in four important areas: economic participation and career opportunities, education, health and survival, political rights and opportunities.

Bearing in mind the indicators of past years, it can be argued that the state of gender equality in Ukraine has considerably deteriorated. Thus, in 2006 in the rating THE GLOBAL GENDER GAP INDEX Ukraine took 48th place. It should be noted that this was the best result for the entire period of state independence. Then for some of the four computational parameters, Ukraine approached the mark of 1.00, which means full gender equality in this area (Количева 2018: 42). So, Ukraine's best practices are traditionally in the area of access of both sexes to education. In particular, it is reported about the almost complete coverage of primary and secondary levels of education. With regard to higher education, women even have better indicators (in the range of 88 to 77 ) (Количева 2018: 43).

Consequently, modern realities of Ukrainian society require a new paradigm of state power, which should provide for the optimal use of human resources, in particular its female component. Despite the fact that some progress has been made in the society on the reduction of gender inequalities in economic, political, social and cultural life, there continue to be various, albeit less obvious, often veiled forms of discrimination. Despite the rapid pace of development of gender legislation and significant progress in gender equality in Ukraine, significant gender imbalances in access to resources and economic opportunities remain in Ukraine. These discrepancies significantly limit women's socio-economic development. Gender gaps in access to resources and opportunities for disposing of them are also becoming widespread. Although, recently, women have significantly expanded their presence in politics, but their representation is still far from parity. Women directly suffer the greatest losses from this inequality, but the costs associated with them permeate the whole of society, causing harm to everyone. For this reason, the achievement of gender equality becomes the central moment of development - its refined and independent purpose. It contributes to strengthening the country's capacity for economic growth, poverty reduction and effective public administration. Therefore, the achievement of gender equality is an important part of the development strategy, which is intended to enable all, both men and women, to improve their standard of living. Consequently, the urgency of the issue of gender equality in the modern historical context will certainly remain in the near future. This is because the problem of gender inequality and socio-economic and political discrimination of women cannot be solved only by reforms by the state. The system of norms prohibiting any worsening of women's rights is unlikely to work without an effective system of control over the implementation of these norms. To solve the 
problem, people need social changes in their minds and, accordingly, an objective view of the problem. From this perspective, priority should be given to the situation of women, especially in those problem areas where clear and hidden forms of discrimination persist, and special measures should be developed, including legislative ones, aimed at achieving real equality of opportunities for men and women, equalizing their social status.

Taking into consideration all of the foregoing, we can conclude that gender equality contributes to the formation of a new, contemporary ideology of equality and includes the following components: gender equality is seen as an integral part of all policies, programs and projects; the achievement of gender equality requires recognizing that the specific interests of women and men must be taken into account when formulating policies, implementing programs and projects; achieving gender equality means that equal rights and opportunities must be ensured regardless of gender; women's access to decision-making at all levels is central to achieving gender equality. To achieve gender equality is important to ensure equal participation of men and women as equal entities in economic, social and cultural processes. Gender equality can be achieved through partnerships between women and men based on the principles of parity democracy.

\section{REFERENCES}

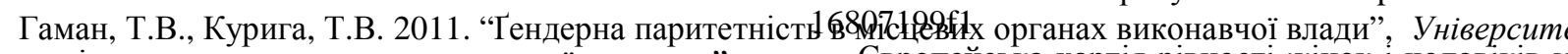
в місцевих органах виконавчої влади”, Університетські наукові записки 2 (38): 417-424.

Крочук, М.I. 2011. "Гендерна рівність як складова загального принципу права”, Науковий вісник Львівського державного університету внутрішніх справ. Серія юридична 4: 466-471.

Дашковська, О.Р. 2014. "Принцип гендерної рівності: поняття, витоки і роль на сучасному етапі розвитку суспільства", Порівняльно-аналітичне право 5: 20-23.

Грицяк, Н.В. 2006. "Базові концепції та ідеї гендерної теорії”, Стратегічні пріоритети 1: 7987.

Кобилянська, Л. 2005. 50/50: сучасне тендерне мислення: словник. Київ.: Видавець К.І.С.

Грицяк, Н. 2004. Формування тендерної політики в Україні: проблеми теорї, методології, практики: монографія. Київ.: Видавництвово НАДУ.

Конвенція ООН про ліквідацію всіх форм дискримінації щодо жінок (CEDAW), прийнята у 1979 p. Стаття 7. URL: http://www.un.org/ womenwatch/daw/cedaw/

Пекінська декларація та платформа дій, IV світова конференція жінок, ООН, вересень 1995 р. Параграф 7. URL: http://www.un.org/ womenwatch/daw/beijing/platform/
Пекінська декларація та платформа дій, IV світова конференція жінок, ООН, вересень 1995 р. Параграф 9. URL: http://www.un.org/ womenwatch/daw/beijing/platform/

Пекінська декларація та платформа дій, IV світова конференція жінок, ООН, вересень 1995 р. H1, H2, H3, параграфи 196-208. URL: http://www.un.org/womenwatch/daw/beijing/platform/

8 резолюцій Ради Безпеки ООН «Жінки, Мир, Безпека» є: 1325 (2000); 1820 (2009); 1888 (2009); 1889 (2010); 1960 (2011); 2106 (2013); 2122 (2013); 2242 (2015).URL: http://www.peacewomen.org/whyWPS/solutions/resolutions/

Основоположна резолюція «Жінки, Мир, Безпека», Офіс спеціального радника 3 гендерних питань та розвитку можливостей жінок (OSAGI). URL: http://www.un.org/womenwatch/osagi/wps

Білосорочка, C.I. 2017. "Гендерна рівність у ратифікованих Україною міжнародно-правових документах" , Теорія та практика державного управління 4 (59): С. 1-6.

Рекомендація CM/REC 17 країнам-членам про стандарти гендерної рівності та механізми, Комітет міністрів Ради Свропи, 21 листопада 2007 р. URL: http://wcd.coe.int/VienDoc.jsp?p=\&Ret=CM/Rec (2007) 17

Рекомендація 148 про гендерний підхід на місцевому та регіональному рівнях: стратегія сприяння рівності між жінками та чоловіками в містах та регіонах. Конгрес місцевих та регіональних влад Ради Європи, 27 травня 2004 року. URL: http://rm.coe.int/168071a54f

Проект 3 питань гендерно чутливого бюджетування в Україні («GRB project»). URL: http://grbprolect.org/

Резолюція 391 про боротьбу із зростаючою бідністю серед жінок: відповідальність місцевих та регіональних органів влади, Конгрес Ради Свропи, 21 жовтня 2015 року. URL: http://rm.coe.int/ Європейська хартія рівності жінок і чоловіків у житті місцевих громад, Рада Європейських муніципалітетів та регіонів, травень 2006 рік, м. Інебрук. URL: http://www.ccre.org/does/charte.egolite .en.pdf

План дій СС з гендерних питань на 2016 - 2020 роки. URL: https://europa.eu/capacity4dev/ publicgender/minisite-gender-action-plan-2016-2020

Про забезпечення рівних прав і можливостей жінок i чоловіків.Закон України Відомості Верховної Ради України. 2005. URL: http://zakon0.rada.gov.ua/laws/show/2866-IV

Законодавство України 3 гендерної рівності. URL: http://www.legislationline.org/topics/topic/7/cou ntry/52

Конвенція Ради Свропи про запобігання насильству стосовно жінок і домашньому насильству (CETS № 210), Рада Європи, 11 травня 2011 p. URL: https://www.coe.int/en/web/ conventions/full-list/-/conventions/treaty/210 (дата зверення 12.05.2019).

cedawّДомашнє насильство відтепер є кримінальним злочином в Україні”, Агенство УНІАН, 7 грудня 2017 p. URL: https://www.unian. info/society/ 2285764-domestic-violence-now-criminal-offense-inukraine.html 


\section{Вісник ХНУ імені В. Н. Каразіна, серія «Питання політологї̈,, вип. 35, 2019}

Постанова Кабінету Міністрів України № 390 "Про Урядового уповноваженого 3 питань гендерної політики”, від 7 липня 2017 року. URL: http://zakon2.rada.gov.ua/laws/show/3902017-\%D0\%BF

Количева, Ю.О. 2018. “Гендерна нерівність в Україні та недосконале законодавство як причина iї виникнення", Актуальні питання сьогодення. T.1: 40-46.

\section{REFERENCES}

Haman, T.V., Kuryha, T.V. 2011. "Gender Parity in Local Executive Bodies", University Scientific Notes 2 (38): 417-424 (in Ukrainian).

Krochuk, M.I. 2011. "Gender equality as a component of the general principle of law", Scientific Bulletin of Lviv State University of Internal Affairs. The series is legal 4: 466-471 (in Ukrainian).

Dashkovska, O.R. 2014. "The principle of gender equality: concepts, origins and role at the present stage of society development", Comparative-analytical law 5: 20-23 (in Ukrainian).

Hrytsiak, N.V. "Basic Concepts and Ideas of Gender Theory", Strategic Priorities 1: 79-87.

Kobylianska, L. 2005. 50/50: Contemporary Gender Thinking: A Dictionary. Kyiv: Vydavets K.I.S. (in Ukrainian).

Hrytsiak, N. 2004. Gender Policy Formation in Ukraine: Problems of Theory, Methodology, Practice: Monograph. Kyiv.: Vydavnytstvo NADU (in Ukrainian).

The United Nations Convention on the Elimination of All Forms of Discrimination against Women (CEDAW), adopted in 1979, Article 7. URL: http://www.un.org/womenwatch/daw/cedaw (in Ukrainian).

Beijing Declaration and Platform for Action, Fourth World Women Conference, UN, September 1995 Paragraph 7. URL: http://www.un.org/ womenwatch/daw/beijing/platform/ (in Ukrainian).

Beijing Declaration and Platform for Action, Fourth World Women Conference, UN, September 1995 Paragraph 9. URL: http://www.un.org/womenwatch/ daw/beijing/platform/ (in Ukrainian).

Beijing Declaration and Platform for Action, Fourth World Women Conference, UN, September 1995 H1, H2, H3, Paragraphs 196 - 208. URL: http://www.un.org/womenwatch/daw/beijing/platform/ (in Ukrainian).

The 8 UN Security Council Resolutions on Women, Peace, and Security are: 1325 (2000); 1820 (2009); 1888 (2009); 1889 (2010); 1960 (2011); 2106 (2013); 2122 (2013); 2242 (2015).

URL: http:// www. peacewomen.org/whyWPS/solutions/ resolutions/(in Ukrainian).

Fundamental Resolution Women, Peace, Security, Office of the Special Advisor on Gender and Women's
Opportunities Development (OSAGI). URL: http:// www.un.org/womenwatch/osagi/wps (in Ukrainian).

Bilosorochka, S.I. 2017. "Gender Equality in the International Legal Instruments Ratified by Ukraine", Theory and Practice of Public Administration 4 (59): 1-6. (in Ukrainian).

CM / REC Recommendation to 17 Member States on Gender Equality Standards and Mechanisms, Council of Europe Committee of Ministers, 21 November 2007 URL: http://wcd.coe.int/Vien Doc.jsp? $\mathrm{p}=\& \operatorname{Ret}=\mathrm{CM} / \operatorname{Rec}(2007) 17$ (in Ukrainian).

Recommendation 148 on gender at local and regional levels: a strategy to promote equality between women and men in cities and regions. Council of Europe Congress of Local and Regional Authorities, May 27, 2004. URL: http://rm.coe.int/168071a54f (in Ukrainian).

The Gender Sensitive Budgeting Project in Ukraine (GRB project). URL: http://grbprolect.org/ (in Ukrainian).

Resolution 391 on Combating Growing Poverty among Women: Responsibility of Local and Regional Authorities, Council of Europe Congress, 21 October 2015. URL: http://rm.coe.int/16807199f1 (in Ukrainian).

European Charter for Equality between Women and Men in the Life of Local Communities, Council of European Municipalities and Regions, May 2006, Innebrook. URL: http://www.ccre.org/does/charte. egolite.en.pdf (in Ukrainian).

EU Gender Action Plan 2016-2020. URL: https://europa.eu/capacity4dev/public-gender/ minisite-gender-action-plan-2016-2020 (in Ukrainian).

On Ensuring Equal Rights and Opportunities for Women and Men. Law of Ukraine of the Verkhovna Rada of Ukraine. 2005. URL: http:// zakon0.rada.gov.ua/laws/show/2866-IV (in Ukrainian).

Legislation of Ukraine on gender equality. URL: http://www.legislationline.org/topics/topic/7/country/5 2 (in Ukrainian).

Council of Europe Convention on the Prevention of Violence against Women and Domestic Violence (CETS No. 210), Council of Europe, 11 May 2011. URL: https://www.coe.int/en/web/conventions/fulllist/-/conventions/treaty/210 (in Ukrainian).

"Domestic violence is now a criminal offense in Ukraine", Ahenstvo UNIAN, 7 hrudnia 2017 r. $U R L:$ https://www.unian.info/society/2285764domestic-violence-now-criminal-offense-inukraine.html (in Ukrainian).

Cabinet of Ministers of Ukraine Resolution No. 390 "On Government Ombudsman for Gender Policy" of 7 July 2017. URL: http://zakon2.rada.gov.ua/laws/ show/390-2017-\%D0\%BF (in Ukrainian).

Kolycheva, Yu.O. 2018. "Gender Inequality in Ukraine and Imperfect Legislation as a Cause of its Emergence", Aktualni pytannia sohodennia. T.1: 4046. (in Ukrainian). 